\title{
INDIVIDUAL ABSORPTIVE CAPACITY AND ENTREPRENEURIAL INTENTION IN SUCCESSORS OF RURAL PROPERTIES
}

\author{
CLAUDETE C. SANTOS ${ }^{1}$ \\ (D) https://orcid.org/0000-0003-2498-0384 \\ SAYONARA F. TESTON ${ }^{2}$ \\ (iD) https://orcid.org/0000-0002-2469-1497 \\ PATRICK ZAWADZKI \\ (iD) https://orcid.org/0000-0001-9290-3968 \\ SUZETE A. LIZOTE \\ (D) https://orcid.org/0000-0003-3575-1675 \\ HILKA P. V. MACHADO \\ (D) https://orcid.org/0000-0002-2554-0025
}

To cite this paper: Santos, C. C., Teston, S. F., Zawadzki, P., Lizote, S. A., \& Machado, H. P. V. (2020). Individual absorptive capacity and entrepreneurial intention in successors of rural properties. Revista de Administração Mackenzie, 21 (3), 1-29. doi:10.1590/1678-6971/eRAMR200045

Submission: Mar. 20, 2019. Acceptance: July 11, 2019.

1 Catarinense Federal Institute (IFC), Luzerna, SC, Brazil.

2 University of Western Santa Catarina (Unoesc), Chapecó, SC, Brazil.

3 University of Vale do Itajaí (Univali), Biguaçu, SC, Brazil.

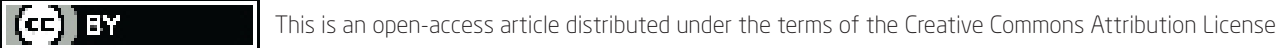

\footnotetext{
This paper may be copied, distributed, displayed, transmitted or adapted if provided, in a clear and explicit way, the name of the journal, the edition, the year and the pages on which the paper was originally published, but not suggesting that RAM endorses paper reuse. This licensing term should be made explicit in cases of reuse or distribution to third parties. It is not allowed the use for commercial purposes.

Este artigo pode ser copiado, distribuído, exibido, transmitido ou adaptado desde que citados, de forma clara e explícita, o nome da revista, a edição, o ano e as páginas nas quais o artigo foi publicado originalmente, mas sem sugerir que a RAM endosse a reutilização do artigo. Esse termo de licenciamento deve ser explicitado para os casos de reutilização ou distribuição para terceiros. Não é permitido o uso para fins comerciais.
} 


\section{ABSTRACT}

Purpose: This study sought to explore the association between the constructs individual absorptive capacity and entrepreneurial intention in successors of rural properties in a cooperative system.

Originality/value: The contribution presented expands the field of entrepreneurship studies and family succession, as well as it brings elements for the management of rural properties. Empirically, the results offer new elements for managers of cooperatives and other similar organizations to formulate strategies to assist in the preparation of the successors' dilemma.

Design/methodology/approach: The design of the adopted method followed a quantitative approach, of descriptive level, of the type survey, and transverse section. The study included 84 successors of rural properties, who were participants in a Skills Development Program for the continuity of young people in the management of properties. Questionnaires were used to evaluate the constructs of individual absorptive capacity and entrepreneurial intention. The statistical analysis used the Kruskal-Wallis with the Dunn post hoc adjusted by the BenjaminiHochberg FDR method, Spearman correlation, and modeling structural equations with estimation by Partial Least Squares.

Findings: The main conclusion of the study suggests that the successors with greater perceived behavioral control assimilate and transform more knowledge with applicability potential in the succession management in rural properties.

\section{KEYWORDS}

Individual absorptive capacity. Entrepreneurial intent. Family businesses. Successors. Rural properties. 


\section{INTRODUCTION}

The absorptive capacity, associated with innovation and learning, is a type of dynamic capacity that leads to the creation and use of knowledge, which can improve a company's ability to obtain and sustain competitive advantage (Cohen \& Levinthal, 1990; Yildiz, Murtic, Zander, \& Richtnér, 2019; Zahra \& George, 2002). Other studies have broadened the approach of the phenomenon by focusing on the influence of the individuals' ability to absorb knowledge and use them for organizational purposes (Jones, 2006; Lowik, Kraaijenbrink, \& Groen, 2016). However, studies at this level of analysis of the phenomenon are still restricted to demonstrate the ability of individuals to promote change (Volberda, Foss, \& Lyles, 2010; Gilstrap \& Hart, 2012) companies and entrepreneurial opportunities.

Entrepreneurial intent (EI) is one of the determinants of starting a new business or of identifying and exploiting opportunities (Shapero \& Sokol, 1982), being a predictor of organizational activity (Obschonka, Silbereinsen, \& Schmitt-Rodermund, 2010). In general, studies on this theme are based on Ajzen's (1985) theory of planned behavior (TPB), which advocates that the action of individuals results from desire, viability and propensity to act. As a subjective process, entrepreneurial intent continues to be the object of studies that seek to broaden the explanation of TPB and include other variables such as self-efficacy (Moraes, Iizuka, \& Pedro, 2018). The association between entrepreneurial intent and individual absorptive capacity (IAC) has not been the subject of previous studies, although there is evidence that the IAC knowledge is associated with desired ends (Bolisani \& Bratianu, 2018; Koerich, Cancellier, \& Tezza, 2015; Hotho, Becker-Ritterspach, \& SakaHelmhout, 2012; Minbaeva, Pedersen, Björkman, \& Fey, 2014).

In this way, this research aimed to explore the association between the constructs IAC and entrepreneurial intention in successors of rural family enterprises. To achieve this objective, a comparison of the dimensions of the constructs with the age categories of the participants was carried out, then, the correlation between the dimensions of the constructs was verified and, finally, the relation between the items of the constructs dimensions was evaluated.

Family succession is important for the survival of rural enterprises and lacks additional studies, as young people residing on rural properties are opting for migration to urban centers (Matte, Spanevello, Lago, \& Andreatta, 2019). Keeping family involvement in rural property results in other benefits, 
such as trust among members and trustworthiness of information (Oliveira \& Vieira Filho, 2018). The IAC is important for the preparation of successors of rural enterprises, because it concerns the preparation of the successor to seek external knowledge and apply them in the management of the property (Lowik et al., 2016), and it can also favor the development of successors' abilities (Sciascia, D’Oria, Bruni, \& Larrañeta, 2014). Entrepreneurial intent, in turn, has its relevance associated with the ability of successors to identify and exploit opportunities, which can favor innovation and growth of enterprises (Shapero \& Sokol, 1982).

This article presents the results of the research carried out with small successors of enterprises and is structured in six sections, beginning with this introduction. Next, a theoretical review is presented, addressing the themes of absorptive capacity and entrepreneurial intention. Following, the methodological procedures are shown, followed by the presentation and discussion of the research results and, then, the considerations.

\section{THEORETICAL REVIEW}

\subsection{Absorptive capability}

The capacity for absorption of knowledge or, absorptive capacity, emerged with the need to obtain external knowledge and incorporate it into organizations while maintaining competitiveness. The absorptive capacity (Acap) construct began in the late 1980s, based on Cohen and Levinthal's (1989) research, defined as the company's ability to identify, assimilate, and apply knowledge.

On the basis of Cohen and Levinthal (1989) seminal definition, other researchers (Lane, Koka, \& Pathak, 2006; Van Den Bosch, Volberda, \& Boer, 1999; Zahra \& George, 2002) have provided alternative contributions to the construct. Different constituent dimensions have been identified and a new definition for absorptive capacity has been proposed as "a set of routines and organizational processes by which companies acquire, assimilate, transform and exploit knowledge to produce dynamic training" (Zahra \& George, 2002, p. 186). However, operationalizing it is a complex task and requires a multidisciplinary approach (Jansen, Van Den Bosch, \& Volberda, 2005; Volberda et al., 2010; Flatten, Engelen, Zahra, \& Brettel, 2011).

Zahra and George (2002) suggest that the construct should be understood from two natures and four distinct but complementary capacities that make up the ability to absorb knowledge: 
- Acquisition: it represents the company's ability to identify externally generated knowledge that impacts its activities.

- Assimilation: ability to analyze, process, interpret and understand the information obtained through external sources.

- Transformation: the organization's ability, based on assimilated knowledge, to redefine actions by combining new and existing knowledge (this dimension has a fundamental role in identifying new opportunities and in changing the way the organization relates to the environment).

- Exploration: ability to refine and take advantage of assimilated knowledge.

Jones (2006) extends the work of Zahra and George (2002), giving greater emphasis to individual agency to understand how organizations absorb new knowledge. Lane et al. (2006), in an attempt to stimulate contributions on absorptive capacity, developed a study, in which they analyzed 289 articles on absorptive capacity. They assessed how the construct had been used and identified substantial contributions to the literature.

A critical article on Zahra and George's model (2002) arose proposing substantive changes in this, based on empirical research. Todorova and Durisin (2007) demonstrate the reintroduction of recognizing value, alternative understanding of transformation, clarification of the potential for absorption capacity, and elaboration of the socialization mechanisms impacts, questioning power relations and the inclusion of feedback loops in a dynamic model.

Fundamentally, the absorptive capacity of an organization depends on the ability of its members to recognize external knowledge, align it with organizational capabilities, and promote its use in the organization (Cohen \& Levinthal, 1990). The firm's internal learning processes are the basic elements of the absorptive capacity, which are related to a continuous acquisition, distribution and use of relevant external knowledge within the company (Versiani, Cruz, Castro, Ferreira, \& Guimarães, 2010). The understanding and interpretation of the knowledge acquired in the external environment are dependent on the assimilation capacity of each individual in the organization (Cohen \& Levinthal, 1990; Silva et al., 2016; Fuchs, Rosseto, \& Carvalho, 2016). Flatten, Greve, and Brettel (2011) emphasize that the individual and collective absorptive capacity depends on the experience accumulated in dealing with the different market situations and their alternations over time, making internal structures and routines more prepared to absorb knowledge. In this sense, Fuchs et al. (2016, p. 150) clarify that 
[...] the total absorptive capacity of the firm will depend on the articulation previously developed in the routines and processes, to facilitate its dissemination and cooperation among the people in the organization, in the continued success of generation of changes and adaptations.

For Lowik et al. (2016), the individual and collective characteristics of the team complement each other, and knowledge creation is a complex phenomenon that includes interactions between individual and group factors.

Most of the studies are based on country analyzes, at the intraorganizational and inter-organizational group levels (Lane et al., 2006; Volberda et al., 2010). However, it is understood that individual observations are more adequate arguments to better explain the micro fundamentals of organizational change (Gilstrap \& Hart, 2012; Tian \& Soo, 2014; Lowik et al., 2016).

Therefore, the present study, based on Tian and Soo (2014) model, focuses on the role of individuals in acquisition (AQ), assimilation (AS), transformation (TR), and application (AP) knowledge, addressing what Lane et al. (2006) and Volberba et al. (2010) have already argued to be a pressing need for understanding the absorptive capacity.

The ICA considers memory as associative, and this contributes to improving the learning process, enhancing knowledge. This process has a cumulative character (Cohen \& Levinthal, 1990; Vega-Jurado, GutiérrezGracia, \& Fernández-de-Lucio, 2008). The absorptive capacity of the organization resides in the individual structures, being applied in the groups and in the organization as a whole (Cohen \& Levinthal, 1990).

The absorptive capacity of the organization is dependent on the individual skills and knowledge that compose it. In this sense, it is considered as one of the main determinants of the creation and sharing of knowledge within organizations (Tian \& Soo, 2014). For this reason, the organization needs human resources prepared for the demands of procedures, routines, resources and power of relationship to aggregate in its performance (Cohen \& Levinthal, 1990).

Cannon, Geddes, and Feinstein (2014) point out that, when the individual faces and recognizes how important information is in the external environment, he/she absorbs that knowledge and applies it, characterizing an individual process. The result implies an amplitude of acquired knowledge and interpretation of the new information (Khosravi, Rezvani, Maduka, 
\& Melville, 2012; Engelen, Kube, Schmidt, \& Flatten, 2014). Therefore, the greater the incentive in learning, the greater the results to be achieved (Khosravi et al., 2012).

\subsection{Entrepreneurial intent}

The formalization of the research on EI began with the studies of Shapero (1984) Shapero and Sokol (1982), and Ajzen (1985, 1991). Subsequently, with the work of Autio, Kenney, Mustar, Siegel, and Wright (2014), Fayolle and Gailly (2014), Saeed, Yousafzai, Yani-De-Soriano, and Muffatto (2015), Khuong and An (2016), Souza and Silveira (2016), Ferreira, Loiola, and Gondim (2017), Paiva, Lima, Rebouças, Ferreira, and Fontenele (2018), Braum and Nassif (2018), and Martins, Santos, and Silveira (2019).

Krueger and Carsud (1993) presuppose that the intention to start a new business has as antecedents the desire in this achievement, the viability and the propensity to act on opportunities. EI is the commitment to start a new business, that is, a predisposition for an individual to create it. Thus, for Ajzen (1991), intention encompasses motivational factors that inspire behavior. Such factors indicate how strong is the will to try or how much effort the individual develops to show a behavior.

Lopez Jr. and Souza (2008) treat EI as real individual behavior and a set of social, cultural, and economic variables that influence the willingness to start a business. Intention can be defined as a state of mental awareness that directs attention, experience and individual behavior to planned business behavior and is still seen as the strongest predictor variable of business activity being widely studied from the point of view of entrepreneurship (Bird, 1988; Obschonka et al., 2010).

For Paiva et al. (2018), EI is directly linked to entrepreneurship, and can be considered as an individual process. Entrepreneurship, in turn, is the key to innovation, productivity and competitiveness in a "dynamic process of vision, change and creation that requires the application of energy and passion for the creation and implementation of innovative ideas and creative solutions" (Kuratko, 2016, p. 5). The entrepreneur is not only executor, he is a thinker, because he plans before acting. "An entrepreneur is an actor who innovates, recognizing opportunities; he or she makes moderately risky decisions that lead to actions which require the efficient use of resources and contribute an added value" (Filion, 2011, p. 8).

However, there is no consensus on the variables that influence the individual's decision to start a venture. Cognitive approaches involve con- 
siderable interest and are crucial in understanding decision-making related to business creation (Shaver \& Scott, 1991; Krueger, 2000; Baron \& Ward, 2004). Para Fayolle and Liñán (2014), the predominant perspective in the cognitive behavioral approach to entrepreneurship turns to the entrepreneurial intention, integrating diverse personality traits and a range of related values (Espíritu-Olmos \& Sastre-Castillo, 2015).

Moraes et al. (2018) created a model to explain the EI through three aspects: self-efficacy, influenced by sociability, leadership, planning and innovation; assumption of risks; and university environment. The results showed that the mentioned aspects were considered direct influencers of the EI.

In the theoretical field, there are several models that address the EI. Krueger and Carsud (1993) applied in a pioneering way in the scope of the entrepreneurship the TPB, presented and proposed by Ajzen (1991). TCP predicts that behavior and intention to act result from the combination of three attitudes: 1 . individual behavior; 2 . the subjective norm implicit in it; and 3. perception about perceived behavioral control. For Almeida and Sobral (2005) TPB has become one of the most widespread theories about human behavior in the context of social sciences and has been tested in several studies as an explanatory model, whose results reveal satisfactory explanatory capacity.

Intent is considered the best independent predictor of behavior (Ajzen, 1991, 2001). The variables that influence intentions are called motivational antecedents (Ajzen, 1991). Thus, the EI is greater when the three antecedents or attitudes are favorable to the behavior, what makes the individual more propitious to realize it (Ajzen, 1991; Liñán, 2004).

Although TCP is criticized for not ensuring what this entrepreneur will undertake, it assists in understanding the formation of EI (Fayolle, Gally, \& Lassas-Clerc, 2006; Souitaris, Zerbinati, \& Al-Laham, 2007; Liñán \& Chen, 2009), and it turned out to be an important model of cognitive evaluation process (Koe, Sa'ari, Majid, \& Ismail, 2012). The model explains the complexity of the relationship between human behavior and determinants. The most important is the identification of human behavior as the cause of the intention.

From this, Liñán and Chen (2009) adapted the model developed by Ajzen (1991) for the manifestation of human behavior in certain situations and created an instrument with the objective of measuring the EI. The instrument is composed of four subscales, being: attitude towards entrepreneurship (ATE), subjective norms (SN), perceived behavioral control (PBC) and objective entrepreneurial intention (OEI) (Liñán \& Chen, 2009). 
ATE is related to positive or negative personal assessment of the individual being an entrepreneur (Kolvereid, 1996; Ajzen, 2001; Autio, Keeley, Klofsten, Parker, \& Hay 2001). It includes not only the affective traits, but it also considers an evaluation (Liñán \& Chen, 2009). SN measures the perceived social pressure to carry out entrepreneurial behavior or not. In particular, it refers to the perception that reference persons would approve or not the decision to become an entrepreneur (Ajzen, 2001). PBC is defined as the perception of the individual's ease or difficulty in performing a certain behavior, based on past experiences, impediments and obstacles; and OEI evaluates the respondent's intention to become an entrepreneur (Liñán \& Chen, 2009).

In the model of Liñán and Chen (2009), there is a particularity: they studied if the subjective norm can influence both the ATE and the PBC, but this hypothesis was not confirmed. As already described by Liñán and Santos (2007), SN is a specific form of social capital and has a causal effect on the other two antecedents of EI.

For Fontenele, Brasil, and Sousa (2015), in the EI process, the components of TCP must be added to other aspects, such as demographic, cultural, business and family trajectories. Such factors may facilitate or hinder entrepreneurial action. Bergmann, Hundt, and Sternberg (2016) emphasize the contextual perspective, especially college that can contribute to the formation of the EI.

Furlan, Angnes, and Morozini (2018) described the process of absorptive capacity on rural properties of cooperative farmers in Paraná, being able to broaden the understanding of the dynamic capacities in the rural environment, but did not perform associations with other constructs. Sznitowski and Souza (2016) have already been able to associate the absorptive capacity with the technological innovation opportunities in Mato Grosso soybean producing properties, showing that the search for knowledge, even among experienced managers, needs to be constant, whether they are drawn from specialized institutions or from specialist professionals. This propensity to search for knowledge can be an entrepreneurial characteristic, which points to a type of attitude, norm or behavior.

Understanding that there are changes in succession patterns in rural areas (Boscardin \& Conterato, 2018; Wheisemer, 2019) and from the theoretical conceptions presented, the objective was to explore the association between the constructs IAC and entrepreneurial intention in successors of rural properties in a cooperative system, starting from the hypothesis that there is a significant and positive $\left(\mathrm{H}_{+}\right)$relation between these constructs (Figure 2.2.1). 


\section{(Figure 2.2.1) \\ HYPOTHESIS OF THE STUDY}

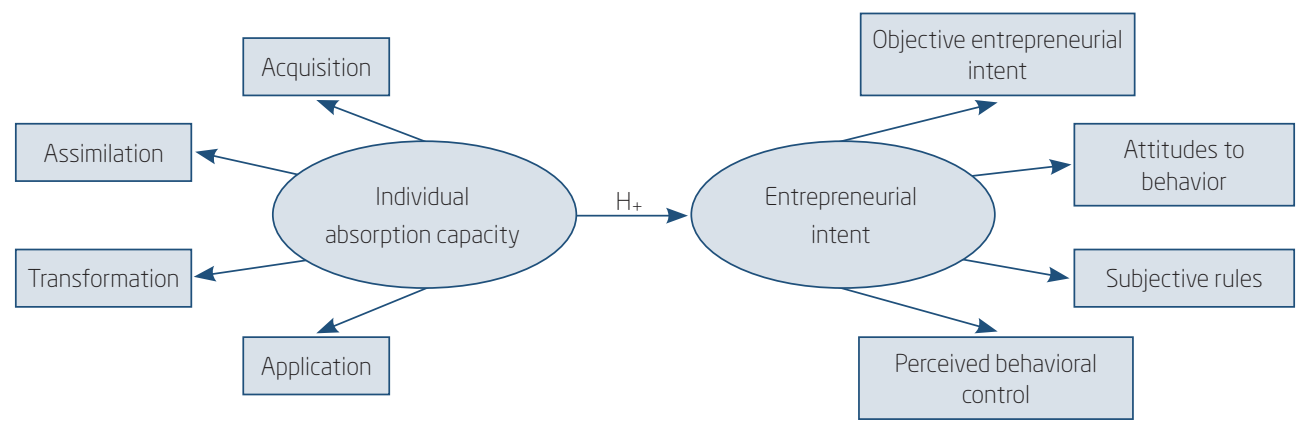

Note: Circles represent the constructs and rectangles, the dimensions. Bivariate relationships and comparisons on dimensions and multivariate relationships were tested on items of dimensions directly associated with the constructs.

\section{METHODOLOGICAL PROCEDURES}

The research was conducted under the quantitative approach, descriptive level, survey type and cross-sectional.

The participants were 84 successors of rural properties associated with a cooperative from Santa Catarina. All participants in a Skills Development Program aimed at the continuity of these young people in the management of properties, as well as the continuity of ownership as an associate of the cooperative. The total number of successors of rural properties associated with the cooperative is unknown, therefore, the selection of the participants was carried out unintentionally and open to all members of the cooperative. All 84 successors in the program accepted to participate in the data collection through a survey, held in September 2017, during meetings in three municipalities.

The constructs were measured using self-filling questionnaires. The IAC construct was measured using an instrument created by Tian and Soo (2014). The same considers the dimensions: acquisition (AQ), assimilation (AS), transformation (TR), and application (AP). Tian and Soo's instrument (2014) is originally composed of 24 items. To measure the EI construct, the variables employed were based on Liñán and Chen's (2009) model of Ajzen's TPB (1991). It was composed of four subscales: objective entrepreneurial intent (OEI), attitudes to behavior (ATB), subjective norms (SN), and 
perceived behavioral control (PBC), totaling 18 items. The alternatives of both instruments were answered on a 5-point Likert scale, ranging from totally disagree (1) to fully agree (5). Demographic data on age (categorized with two cut-off points based on percentage), sex, schooling, and marital status of the participants were collected, and information was collected on whether or not there was an intention to continue working on parental ownership and on continuing in the segment of agribusiness.

Initially, the data was organized, coded, and processed using Excel $^{\circledR}$ spreadsheet and the SPSS ${ }^{\circledR}$ (Statistical Package for the Social Science) software, version 21 (IBM Corporation, 2012). Subsequently, the analysis used descriptive statistics and differentiation to characterize the sample, bivariate tests to relate the instrument dimensions, and finally, multivariate statistics to explore relationships between the constructs. The variables' abnormal distribution was verified by the Kolmogorov-Smirnov test and asymmetry and kurtosis. In all analyzes, the significance level adopted was 0.05.

In the descriptive analysis, absolute frequency $(n)$, relative frequency $(\%)$, and median (md) were used because they are ordinal variables, confidence intervals 95\% (IC95\%), the Kruskal-Wallis test of independent samples and the post hoc in Dunn, with the FDR method of BenjaminiHochberg. In the constructs relation analysis, Spearman $(\rho)$ correlation tests were applied. For the multivariate analysis, the data were transferred to the software Adanco ${ }^{\circledR}$, version 2.0.1 (Henseler, 2017). The technique of modeling structural equations (MEE) was used with estimation by Partial Least Squares (Hair Jr., Hult, Ringle, \& Sarstedt, 2014). The technique was adopted because the hypothesis of this study intends to contribute with the development of the theory (Riel, Henseler, Kemény, \& Sasovova, 2017), an abnormality of the distribution was found, and the sample is statistically small $(n<400)$, despite its high representativeness for the studied population (Hair Jr. et al., 2014).

\section{RESULTS PRESENTATION}

\subsection{Characterization of participants}

The study participants, in the data collection period, were between 15 and 53 years old, and $32.1 \%$ (27 people) were up to 19.38 years, $32.1 \%$ (27), between 19.39 a 23.24 , and $35.7 \%$ (30), 23.25 or more. In total, $40.5 \%$ (34) were women and $59.6 \%$ (50), men. Regarding schooling, $4.8 \%$ (4) studied 
until elementary education, $66.6 \%$ (56), until high school, and $28.6 \%$ (24) are attending (21) or concluded (3) higher education. Of the total participants, $32.1 \%$ (27) were married, and $67.9 \%$ (57) were single. When questioned about ownership plans, $69 \%$ (58) wanted to succeed their parents, $3.6 \%$ (3) did not wish to succeed them, and $27.4 \%$ (23) mentioned that they might succeed their parents. When questioned about the intention to continue working in the agribusiness segment, $78.6 \%$ (66) stated yes, $3.6 \%$ (3) stated no, and $17.9 \%$ (15) stated that maybe they would continue in the segment. Figure 4.1.1 shows the values obtained in the dimensions of the study constructs, comparing the age groups. The values were obtained by the median and confidence interval at $95 \%$.

\section{(Figure 4.1.1)}

\section{COMPARISON OF CONSTRUCT DIMENSIONS BY AGE CATEGORIES}

\begin{tabular}{|c|c|c|c|c|}
\hline & \multicolumn{4}{|c|}{ Age } \\
\hline & $\begin{array}{c}\leq 19.38 \text { years } \\
(n=27)\end{array}$ & $\begin{array}{c}\text { 19.39-23.24 years } \\
(n=27)\end{array}$ & $\begin{array}{c}\geq 23.25 \text { years } \\
\quad(n=30)\end{array}$ & $p$-valor \\
\hline Individual absorptive capacity & $m d(I C 95 \%)$ & $m d(I C 95 \%)$ & $m d(I C 95 \%)$ & \\
\hline Acquisition & $4.00(3.60-4.14)$ & 4.00(3.77-4.19) & $4.00(3.96-4.35)$ & 0.095 \\
\hline Assimilation & $4.00(3.26-3.85)$ & $3.00(3.11-3.70)$ & $4.00(3.67-4.05)$ & 0.056 \\
\hline Transformation & $4.00(3.41-3.99)$ & $4.00(3.40-3.93)$ & $4.00(3.62-4.12)$ & 0.284 \\
\hline Application & $4.00(3.76-4.32)$ & $4.00(3.80-4.27)$ & $4.00(4.08-4.52)$ & 0.184 \\
\hline Entrepreneurial intent & $m d(I C 95 \%)$ & $m d(I C 95 \%)$ & $m d(I C 95 \%)$ & \\
\hline Objective entrepreneurial intent & $4.00(3.29-4.19)$ & $4.00(3.53-4.29)$ & $4.50(4.17-4.66)$ & $0.037^{\star}$ \\
\hline Behavioral attitudes & $4.00(3.58-4.31)$ & $4.50(4.01-4.58)$ & $4.75(4.25-4.72)$ & 0.050 \\
\hline Subjective rules & $4.00(3.72-4.20)$ & $4.00(3.42-4.07)$ & $4.50(3.76-4.50)$ & 0.081 \\
\hline Perceived behavioral control & $3.50(2.95-3.60)$ & $3.50(3.02-3.68)$ & $3.50(3.23-3.90)$ & 0.654 \\
\hline
\end{tabular}

* Significant difference $(p=0.046$ ) between $\leq 19.38$ years and $\geq 23.25$ found by Dunn post hoc adjusted by the FDR method of Benjamini-Hochberg.

EI, evaluated by four items, was the only dimension that presented significant differences in age, post hoc of Dunn revealed that the younger ( $\leq 19.38$ years) have a lower level of EI than the older ones ( $\geq 23.25$ years) of the sample. 


\subsection{Bivariate relationships between constructs}

Figure 4.2.1 presents the bivariate correlation coefficients of Spearman ( $\rho$ ) between the construct instruments. In the dimensions of IAC, all correlations were significant at a level below 0.01. In the dimensions of EI, two correlations were found at a level lower than 0.01 and one at 0.05. All the correlations found have a positive meaning. The coefficients obtained had their magnitude classified according to the proposal of Cohen (1988), where values between 0.10 and 0.29 are considered small; between 0.30 and 0.49 are considered average; and between 0.50 and 1 are explained as large.

\section{(Figure 4.2.1)}

\section{CORRELATIONS BETWEEN INSTRUMENT DIMENSIONS}

\begin{tabular}{|c|c|c|c|c|c|c|c|c|}
\hline & $A Q$ & AS & TR & AP & OEI & ATB & SN & $\mathrm{PBC}$ \\
\hline \multicolumn{9}{|c|}{ Individual absorption capacity } \\
\hline$A Q$ & 1 & & & & & & & \\
\hline AS & $0.455^{\star \star}$ & 1 & & & & & & \\
\hline $\mathrm{TR}$ & $0.458^{\star \star}$ & $0.514^{\star \star}$ & 1 & & & & & \\
\hline AP & $0.292^{\star \star}$ & $0.329 * \star$ & $0.365^{\star \star}$ & 1 & & & & \\
\hline \multicolumn{9}{|c|}{ Entrepreneurial intent } \\
\hline $\mathrm{OEl}$ & $0.226^{*}$ & 0.068 & $0.225^{\star}$ & 0.163 & 1 & & & \\
\hline ATB & $0.252^{*}$ & 0.135 & $0.316^{\star \star}$ & 0.163 & $0.524^{\star \star}$ & 1 & & \\
\hline SN & -0.019 & 0.035 & 0.087 & $0.251^{\star}$ & 0.046 & $0.224^{\star}$ & 1 & \\
\hline $\mathrm{PBC}$ & $0.218^{*}$ & $0.239^{*}$ & $0.341^{\star \star}$ & $0.274^{* *}$ & 0.175 & $0.350^{* *}$ & 0.142 & 1 \\
\hline
\end{tabular}

* Correlation is significant at the 0.05 ; ${ }^{* *}$ correlation is significant at the 0.01 .

Source: Elaborated by the authors.

In IAC, AQ presented a mean magnitude in its correlation with AS (0.455) and TR (0.458), and low magnitude with AP (0.292). AS also showed large magnitude with TR (0.514) and mean with AP (0.329). Also, TR presented mean strength (0.365) with AP. In EI dimensions, significant correlations were found at a level lower than 0.01 between OEI and ATB with large magnitude (0.524) and between ATB and PBC with mean magnitude (0.350). In addition, a significant correlation was also found at a level lower than 0.05 between ATB and SN with small magnitude (0.224). 
Among the dimensions of the IAC and EI constructs, three significant correlations were found at a level lower than 0.01, being, TR and ATB with mean magnitude (0.316), TR and PBC with mean magnitude (0.341), and AP and PBC with magnitude (0.274). In addition, six correlations of small magnitude were significant at a level lower than 0.05, being them AQ and OEI (0.226), AQ and ATB (0.252) and AQ and PBC (0.218), AS and PBC (0.239), TR and OEI (0.225), and AP and SN (0.251).

\subsection{Multivariate relationship between dimensions}

The IAC construct and the EI construct were considered reflexive and independent (Hair Jr. et al., 2014). All variables were considered of the first order.

The process began with the step of debugging the scale for the focus population of this study, whose objective was to eliminate items that presented low factor load and that could compromise the minimum criteria of evaluation for the variables of the study, therefore, only items that presented loads $>0.7$ were maintained (Hair Jr. et al., 2014). Figure 4.3.1 presents the factorial loads of each variable and the composite reliability (CR) of the constructs.

(Figure 4.3.1)

FACTOR LOADINGS AND COMPOSITE RELIABILITY

\begin{tabular}{ccc} 
Variable & Individual absorption capacity & Entrepreneurial intent \\
\hline AS2 & 0.8438 & \\
\hline AS3 & 0.7970 & \\
\hline TR3 & 0.7856 & \\
\hline PBC2 & & 0.7727 \\
\hline PBC3 & 0.8402 \\
\hline PBC6 & & 0.8056 \\
\hline CR & $0.7398^{\star}$ & $0.7322^{\star}$ \\
\hline
\end{tabular}

* Alpha de Cronbach

Source: Elaborated by the authors.

The CR, verified by the alpha Cronbach, refers to the intercorrelation between the observed variables, and the minimum value of 0.7 was considered, which ensures that the constructs were measured consistently (Fornell \& Larcker, 1981; Henseler, Ringle, \& Sinkovics, 2009). In addition, 
convergent validity and discriminating validity were determined, the results of which can be seen in Figure 4.3.2.

(Figure 4.3.2)

CONVERGENT VALIDITY AND DISCRIMINATING VALIDITY

\begin{tabular}{lcc}
\hline & $\begin{array}{c}\text { Individual absorptive } \\
\text { capacity }\end{array}$ & Entrepreneurial Intent \\
\hline Individual absorptive capacity & $0.6548^{*}$ & $0.6594^{\star \star}$ \\
\hline Entrepreneurial Intent & 0.2467 & $0.6506^{\star}$ \\
\hline
\end{tabular}

* Average extracted variance (AEV); ** heterotrait-monotrait(HTMT).

Source: Elaborated by the authors.

The convergent validity refers to the association of the observed variables with the latent variable, which is evaluated through the results obtained for average extracted variance (AEV), and values above $50 \%$ are expected for AEV (Hair Jr. et al. 2014). It is observed that the value exceeded $65 \%$. The values were presented in the bold diagonal of Figure 4.3.2. Discriminating validity refers to the fact that the variable is unique and does not capture phenomena that are not represented by other variables (Hair Jr. et al., 2014). It should be noted that the indicators have higher loads in their latent variables compared to loads of the other variables, showing the discriminating validity by the Fornell-Lacker criterion and the correlation index heterotraitmonotrait - HTMT (Chin, 1998; Henseler et al., 2009; Hair et al., 2014). Figure 4.3.3 presents the hypothesis test of the study and the indexes consistent with the path model.

\section{(Figure 4.3.3) \\ PATH TEMPLATE}

\begin{tabular}{cccccccc}
\hline Way* $^{*}$ & $\begin{array}{c}\text { Coefficient } \\
\text { structural }\end{array}$ & t-value & p-value & $f^{2}$ & $R^{2}$ & $R^{2} \mathrm{Aj}$. & Hypothesis \\
\hline IAC $>$ EI & 0.4967 & 5.8880 & 0.0000 & 0.3276 & 0.2467 & 0.2375 & Supported \\
\hline
\end{tabular}

* Variables variance inflation factor $(V I F)<1.5049$.

Source: Elaborated by the authors.

The structural coefficient represents the relationships between the constructs and has standardized values between -1 and +1 and the $T$ test is 
intended to evaluate the significance of correlations and regressions and should be above 1.96 (Hair Jr. et al., 2014). The Cohen indicator ( $\left.f^{2}\right)$ evaluates how much each construct is useful for the model fit. Values of 0.02, 0.15 and 0.35 are considered small, medium and large, respectively (Hair et al., 2014). For Hair Jr. et al. (2014), the most commonly used measure to evaluate the structural model is the coefficient of determination $\left(\mathrm{R}^{2}\right)$. This coefficient shows the strength of the correlation effect, being $2 \%$ considered small, $13 \%$ considered medium, and $26 \%$ considered large (Cohen, 1988). The values presented in the variance inflation factor (VIF) refer to the collinearity between the variables, and Hair Jr. et al. (2014) suggest that the values should remain between 0.20 and 5. It is verified, therefore, that the hypothesis that there are associations between the evaluated dimensions of IAC concepts and EI in successors of rural properties in a cooperative system was supported.

\section{DISCUSSION OF THE RESULTS}

The Skills Development Program of rural property successors in a cooperative system did not attract only young people, although $46.4 \%$ of the participants were 20 years old or less. The succession process begins when the predecessor demonstrates the intention for the succession to occur, until the moment he definitively leaves the office for another one to assume this position (De Massis, Chua, \& Chrisman, 2008). In this context, the phenomenon of late succession tends to be common in rural enterprises (Brandth \& Overrein, 2013; Matte et al., 2019). According to Matte et al. (2019, p. 25) "the father only leaves from the command of the property when he is no longer able to continue with the work." This may be contributing to the lack of interest of young people in staying in the countryside (Brandth \& Overrein, 2013; Matte et al., 2019). This aspect can be observed in the plans of permanence in the property (since $3.6 \%$ do not want to succeed their parents and $27.4 \%$ may succeed them), as well as in relation to the intention to continue working in the agribusiness segment $(3.6 \%$ declare that they do not intend to continue in the segment and $17.9 \%$ stated that they may continue in the future). Motivational aspects may be associated with entrepreneurial intent (Loiola, Gondim, Pereira, \& Ferreira, 2016) in the investigated group.

It is also observed that the research participants tend to continue the formal study for a longer period, when compared to the national indexes published by the Inter-Union Department of Statistics and Socioeconomic Studies - Dieese (2011). According to these data, only $1.4 \%$ of the rural 
population study 15 years or more, while $28.6 \%$ of the program participants stated that they are attending or completing higher education. It is known that the theme of organizational learning (Easterby-Smith \& Lyles, 2003) is similar to that of IAC.

It is observed that the absorptive capacity does not present significant differences when the age groups are compared. The absorptive capacity refers to the potential to acquire, assimilate, transform and apply knowledge or obtained information (Cannon, Geddes, \& Feinstein, 2014). IAC is considered to be one of the main determinants of knowledge creation and sharing within organizations (Tian \& Soo, 2014), and to manage the rural enterprise is important for young people to be able to absorb information and transform it into applied information in the management of the rural property in a cooperative system.

Especially in the AS dimension, which refers to the ability to analyze, process, interpret and understand the information obtained through external sources (Zahra \& George, 2002), subjects aged between 19.39 and 23.24 years were assessed and (although there was no significant difference) compared to individuals from other age groups, and compared to the other dimensions of IAC. AS step is fundamental to transform information into knowledge, for both individual development and rural property management. To summarize, we can mention Hotho et al. (2012), Minbaeva et al. (2014) and Yildiz et al. (2019), who assert that individuals play a crucial role in the absorption and transfer of knowledge.

The OEI was significantly lower for the younger ( $\leq 19.38$ years) than the older ones ( $\geq 23.25$ years), with OEI considering the convenience and possibility of accepting the risk of undertaking, making an entrepreneur, combining behavior, and intention to act. It refers simultaneously to the desirability of action, the propensity to act and the perception of viability of action (Krueger, Reilly, \& Carsrud, 2000; Peterman \& Kennedy, 2003). It is known that the search for a young person to build an entrepreneurial career is associated with aspects of a contextual nature and also to motivational and attitudinal aspects (Loiola et al., 2016). Although all have sought the Competency Development Program, which aims the continuity of young people in property management, the OEI may be smaller among the younger ones because the family succession tends to be late in the rural environment. There is evidence of the need for mechanisms to stimulate the OEI for young people in the rural context.

The PBC dimension of the EI construct showed a correlation with all IAC dimensions. PBC is related to the perception of individual control over 
behavior (Ajzen, 1991), that is, it refers to a person's beliefs about the degree of ease or difficulty in performing a particular action. Thus, a successor's perception of how much he considers himself capable of performing a particular behavior (Fayolle, Liñán, \& Moriano, 2014) correlates with the ability to acquire, assimilate, transform and apply knowledge or information. The higher the IAC, the more subjects feel able to take control of their own behavior, and vice versa.

For $49.7 \%$ of the successors who participated in the research, the items of the IAC construct: to quickly understand new opportunities to serve property customers (AS2), to quickly understand new opportunities to serve the cooperative's customers (AS3), and meeting with colleagues to discuss how to use new knowledge to improve products that focus on the customers of the property (TR3) are associated with specific items of EI, being: feeling prepared to start a viable business ( $\mathrm{PBC} 2)$, feeling that they can control the process of creating a new rural property (PBC3) and if I tried to create a new rural property, I would have a high probability of success (PBC6). Specific AS skills (especially on new situations) and TR (involving sharing) are significantly associated with specific characteristics of the PBC.

The results showed an association between the EI and IAC constructs, that is, the greater the intention to undertake, the greater the desire to acquire knowledge, transform and apply it to property management (Zahra \& George, 2002), which evidences the strategic complementarity of the two constructs, enabling the formation of successor skills and competences, and, at the same time, dynamic management (Meirelles \& Camargo, 2014).

\section{FINAL CONSIDERATIONS}

In this study, the objective was to explore the association between the IAC and EI constructs in successors of rural properties. It has been identified through the correlation analysis that $\mathrm{PBC}$ is the dimension that has more significant associations to IAC dimensions. The multivariate analysis showed that there is an association between the AS and TR dimensions of IAC with the PBC dimension of EI. Specifically, it is possible to conclude that successors with higher $\mathrm{PBC}$ assimilate and transform more knowledge with application potential within their properties.

It can be observed that the hypothesis confirmation of the study fills theoretical gaps pointed out by Hotho et al. (2012), Minbaeva et al. (2014) 
and Yildiz et al. (2019) since it expands studies in the field of IAC. In addition, it has been shown that the study presents potential empirical gains, since the association between the constructs suggests an important source of competitive advantage for the rural properties, offering elements for cooperative managers to formulate strategies to help in the preparation of the rural successors' dilemma.

As a limitation of the study, it is known that the results cannot be generalized since the study was carried out in only one region of the country and with a specific public. Liñan and Chen (2009) emphasize the influence of culture in the formation of EI. The inherent limitations of working with cross-sectional data are also recognized, as they may be subject to causal effects. Limitations also point to the possibility of future studies. Therefore, in addition to conducting further studies in other regions or with different publics, it is suggested to explore the association of the IAC construct with others, such as self-efficacy and learning, since this study focused on a specific characteristic: EI. It is also suggested to analyze entrepreneur behavior through effectuation so that behavioral questions linked to intuition are also evaluated in the construction of knowledge.

\section{CAPACIDADE ABSORTIVA INDIVIDUAL E INTENÇÃO EMPREENDEDORA EM SUCESSORES DE PROPRIEDADES RURAIS}

Objetivo: Este estudo buscou explorar a associação entre os construtos capacidade absortiva individual e intenção empreendedora em sucessores de propriedades rurais em sistema cooperativista.

Originalidade/valor: A contribuição apresentada expande o campo de estudos de empreendedorismo e da sucessão familiar, bem como traz elementos para a gestão de propriedades rurais. Empiricamente, os resultados oferecem novos elementos para gestores de cooperativas e outras organizações similares para formulação de estratégias, visando auxiliar no dilema do preparo de sucessores.

Design/metodologia/abordagem: O desenho do método adotado seguiu abordagem quantitativa, de nível descritivo, do tipo survey e corte trans- 
versal. Participaram do estudo 84 sucessores de propriedades rurais, os quais foram participantes de um Programa de Desenvolvimento de Competências para continuidade dos jovens na gestão das propriedades. Utilizaram-se questionários para avaliar os construtos capacidade absortiva individual e intenção empreendedora. A análise estatística utilizou as provas de Kruskal-Wallis com o post hoc de Dunn ajustado pelo método FDR de Benjamini-Hochberg, a correlação de Spearman e a modelagem de equações estruturais com estimação por mínimos quadrados parciais. Resultados: A principal conclusão do estudo sugere que os sucessores com maior controle comportamental percebido assimilam e transformam mais conhecimento com potencial de aplicação na gestão da sucessão em propriedades rurais.

\section{$\int$ PALAVRAS-CHAVE}

Capacidade absortiva individual. Intenção empreendedora. Empresas familiares. Sucessores. Propriedades rurais.

\section{REFERENCES}

Ajzen, I. (1985). From intentions to actions: A theory of planned behavior. In J. Kuhl \& J. Beckmann (Eds.). Action-control: From cognitions of behavior (pp. 11-39). Berlin: Springer-Verlag, 1985.

Ajzen, I. (1991). The theory of planned behavior. Organizational Behavior and Human Decision Processes, 50(2), 179-211. doi:10.1016/0749-5978(91) 90020-T

Ajzen, I. (2001). Nature and operation of atitudes. Annual Review of Psychology, $52,27-58$.

Almeida, F. J. R., \& Sobral, F. J. B. A. (2005). Emoções, inteligência e negociação: Um estudo empírico sobre a percepção dos gerentes portugueses. Revista de Administração Contemporânea, 9(4), 9-30. doi:10.1590/S1415-65 552005000400002 
Autio, E., Keeley, R., Klofsten, M., Parker, G. G. C., \& Hay, M. (2001). Entrepreneurial intent among students in Scandinavia and in the USA. Enterprise and Innovation Management Studies, 2(2), 145-160.

Autio, E., Kenney, M., Mustar, P., Siegel, D., \& Wright, M. (2014). Entrepreneurial innovation: the importance of context. Research Policy, 43(7), 1097-1108.

Baron, R. A., \& Ward, T. B. (2004). Expanding entrepreneurial cognition's toolbox: potential contributions from the field of cognitive science. Entrepreneurship Theory and Practice, 28, 553-573.

Bergmann, H., Hundt, C., \& Sternberg, R. (2016). What makes student entrepreneurs? On the relevance (and irrelevance) of the university and the regional context for student start-ups. Small Business Economics, 47(1), $53-76$.

Bird, B. (1988). Implementing entrepreneurial ideas: The case for intention. Academy of Management Review, 13(3), 442-453. doi:10.2307/258091

Bolisani E., \& Bratianu, C. (2018) Generic knowledge strategies. In E. Bolisani \& C. Bratianu. Emergent knowledge strategies: Strategic thinking in knowledge management (pp. 147-174). Cham: Springer. doi:10.1007/978-3-319-60 657-6_7

Boscardin, M., \& Conterato, M. A. (2018). As mudanças nos padrões sucessórios e suas implicações no destino das propriedades entre agricultores familiares no norte do Rio Grande do Sul. Estudos Sociedade e Agricultura, 25(3), 671-695.

Brandth, B., \& Overrein, G. (2013). Resourcing children in a changing rural context: Fathering and farm succession in two generations of farmers. Sociologia Ruralis, 53(1), 95-111. doi:10.1111/soru.12003.

Braum, L., \& Nassif, V. (2018). Estrutura intelectual da produção científica sobre propensão ao empreendedorismo: Uma análise à Luz das cocitações. Administração: Ensino e Pesquisa, 19(3), 422-468. doi:10.13058/raep.2018. v19n3.1047

Cannon, H. M., Geddes, B. C., \& Feinstein, A. H. (2014). Experiential strategies for building individual absorptive capacity. Developments in Business Simulation and Experiential Learning, 41, 378-389.

Chin, W. W. (1998). The partial least squares approach for structural equation modeling. In G. A. Marcoulides (Ed.). Methodology for business and management. Modern methods for business research (pp. 295-336). Mahwah, NJ: Lawrence Erlbaum Associates. 
Chiva, R., \& Allegre, J. (2005). Organizational learning and organizational knowledge: The integration of two approaches. Management Learning, 36(1), 49-68.

Cohen, J. (1988). Statistical power analysis for the behavioral sciences (2nd ed.). New York: Lawrence Erlbaum Associates.

Cohen, W., \& Levinthal, D. (1989). Innovation and learning: The two faces of R\&D. The Economic Journal, 99(397), 569-596.

Cohen, W., \& Levinthal, D. (1990). Absorptive capacity: A new perspective on learning and innovation. Administrative Science Quarterly, 1(35), 128152.

De Massis, A., Chua, J. H., \& Chrisman, J. J. (2008). Factors preventing intra-family succession. Family Business Review, 21(2), 183-199. doi:10.11 11/j.1741-6248.2008.00118.x

Departamento Intersindical de Estatística e Estudos Socioeconômicos (2011). Estatísticas do meio rural 2010-2011. São Paulo: Dieese. Retrieved from https://www.dieese.org.br/anuario/2011/anuarioRural10-11.html

Easterby-Smith, M., \& Lyles, M. A. (2003). The Blackwell handbook of organizational learning and knowledge management. Oxford: Blackwell

Engelen, A., Kube, H., Schmidt, S., \& Flatten, T. (2014) Entrepreneurial orientation in turbulent environments: The moderating role of absorptive capacity.JournalPolicy,43(8), 1353-1369. doi:10.1016/j.respol.2014.03.002.

Espíritu-Olmos, R., \& Sastre-Castillo, M. A. (2015). Personality traits versus work values: Comparing psychological theories on entrepreneurial intention. Journal of Business Research, 68(7), 1595-1598. doi:10.1016/j. jbusres.2015.02.001

Fayolle, A., \& Gailly, B. (2015). The impact of entrepreneurship education on entrepreneurial attitudes and intention: Hysteresis and persistence. Journal of Small Business Management, 53(1), 75-93. doi:10.1111/jsbm.12065Liñán

Fayolle, A., Gailly, B., \& Lassas-Clerc, N. (2006). Effect and counter-effect of entrepreneurship education and social context on student's intentions. Estudios de Economia Aplicada, 24(2), 509-523.

Fayolle, A., \& Liñán, F. (2014). The future of research on entrepreneurial intentions. Journal of Business Research, 67(5), 663-666. doi:10.1016/j. jbusres.2013.11.024

Fayolle, A., Liñán, F., \& Moriano, J. A. (2014). Beyond entrepreneurial intentions: Values and motivations in entrepreneurship. International 
Entrepreneurship and Management Journal, 10, 679-689. doi:10.1007/s11365014-0306-7

Ferreira, A. S. M., Loiola, E., \& Gondim, S. M. G. (2017). Individual and contextual predictors of entrepreneurial intention among undergraduates: A literature review. Cadernos EBAPE.BR, 15(2), 292-308.

Filion, L. J. (2011). Defining the entrepreneur. In L. P. Dana (Ed.). World encyclopedia of entrepreneurship (pp. 41-52). Cheltenham: Edward Elgar.

Flatten, T., Engelen, A., Zahra, S. A., \& Brettel, M. (2011). A measure of absorptive capacity: Development and validation. Academy of Management Annual Meeting Proceedings, 29(2), 98-116. doi:10.1016/j.emj.2010.11.002

Flatten, T. C., Greve, G. I., \& Brettel, M. (2011). Absorptive capacity and firm performance in SMEs: The mediating influence of strategic alliances. European Management Review, 8, 137-152.

Fontenele, R. E. S., Brasil, M. V. O., \& Sousa, A. M. R. (2015). Influência da intenção empreendedora de discentes em um instituto de ensino superior. Revista de Empreendedorismo e Gestão de Pequenas Empresas, 4(3), 147-176.

Fornell, C., \& Larcker, D. F. (1981). Evaluating structural equation models with unobservable variables and measurement error. Journal of Marketing Research, 18(1), 39-50. doi:10.2307/3151312

Fuchs, J. P. S., Rossetto, C. R., \& Carvalho, C. E. (2016). A influência da capacidade absortiva realizada no desempenho da PME vitivinícola. Revista Desenvolvimento em Questão, 14(37), 144-167, 2016. doi:10.21527/22376453.2016.37.144-167

Furlan, M., Angnes, J. S., \& Morozini, J. F. (2018). Capacidade absortiva em propriedades rurais de agricultores associados a uma cooperativa agroindustrial. Cadernos EBAPE.BR, 16(2), 302-317. doi:10.1590/1679-39516 4312

Gilstrap, J. B., \& Hart, T. A. (2012). How employee behaviors contribute to firms' absorptive capacities. Academy of Management Annual Meeting Proceedings, 1, 1. doi:10.5465/AMBPP.2012.316

Hair Jr., J. F., Hult, G. T. M., Ringle, C. M., \& Sarstedt, M. (2014). A primer on partial least squares structural equation modeling (PLS-SEM). London: Sage.

Henseler, J. (2017). Adanco, versão 2.0.1. Kleve: Composite Modeling GmbH $\&$ Co.

Henseler, J., Ringle, C., \& Sinkovics, R. (2009). The use of partial least squares path modelling in international marketing. In R. R. Sinkovics \& 
P. N. Ghauri (Eds.). New challenges to international marketing (pp. 277-319). Bingley, UK: Emerald Group.

Hotho, J. J., Becker-Ritterspach, F., \& Saka-Helmhout, A. (2012). Enriching absorptive capacity through social interaction. British Journal of Management, 23(3), 383-401.

IBM Corporation (2012). SPSS Statistics for Windows, version 21.0. Armonk, NY: IBM.

Jansen, J., Van Den Bosch, F., \& Volberda, H. (2005). Managing potential and realized absorptive capacity: How do organizational antecedent's matter? Academy of Management Journal, 6 (48), 999-1015.

Jones, O. (2006). Developing absorptive capacity in mature organizations: The change agent's role. Management Learning, 37(3), 355-376.

Khosravi, P., Rezvani, A., Maduka, S., \& Melville, P. (2012) Individuals' absorptive capacity in enterprise system assimilation. Proceedings of the Australasian Conference on Information Systems 2012, Geelong, Victoria, Australia, 23.

Khuong, M. N., \& An, N. H. (2016). The factors affecting entrepreneurial intention of the students of Vietnam national university: A mediation analysis of perception toward entrepreneurship. Journal of Economics, Business and Management, 4(2), 104-111.

Koe, W., Sa'ari, J. R., Majid, I. A., \& Ismail, K. (2012). Determinants of entrepreneurial intention among millennial generation. Procedia - Social and Behavioral Sciences, 40, 197-208. doi:10.1016/j.sbspro.2012.03.181

Koerich, G. V., Cancellier, E. L. P. L., \& Tezza, R. (2015). Capacidade de absorção, turbulência ambiental e desempenho organizacional: Um estudo em empresas varejistas catarinenses. Revista de Administração Mackenzie, 16(3), 238-267. doi:10.1590/1678-69712015/administracao.v16n3 p238-267

Kolvereid, L. (1996). Prediction of employment status choice intentions. Entrepreneurship Theory and Practice, 21 (1), 47-58. doi:10.1177/1042258 79602100104

Krueger, N. F. (2000). The cognitive infrastructure of opportunity emergence. Entrepreneurship Theory and Practice, 24(3), 5-23.

Krueger, N. F., \& Carsud, A. (1993). Entrepreneurship intentions: Applying the theory of panned behavior. Entrepreneurship \& Regional Development, 5, 316-323. doi:10.1080/08985629300000020 
Krueger, N. F, Reilly, M. D., \& Carsrud, A. L. (2000). Competing models of entrepreneurial intentions. Journal of Business Venturing, 15, 411-432.

Kuratko, D. F. (2016). Empreendedorismo, teoria, processo e prática (10a ed.). (Noveritis do Brasil, Trad.; Mariana Paes da Fonseca Maia, Rev. téc.). São Paulo: Cengage Learning.

Lane, P., Koka, B., \& Pathak, S. (2006). The reification of absorptive capacity: A critical review and rejuvenation of the construct. Academy of Management Review, 31 (4), 833-863, 2006. doi:10.2307/20159255

Liñán, F. (2004). Intention-based models of entrepreneurship education. Piccola Impresa/Small Business, 3, 11-35.

Liñán, F., \& Chen, Y. (2009). Development and cross-cultural application of a specific instrument to measure entrepreneurial intentions. Entrepreneurship: Theory \& Practice, 33 (3), 593-617. doi:10.1111/j.1540-6520.2009.00318.x

Liñán, F., \& Santos, F. J. (2007). Does social capital affect entrepreneurial intentions? International Advances in Economic Research, 13(4), 443-453.

Loiola, E., Gondim, S. M. G., Pereira, C. R., \& Ferreira, A. S. M. (2016). Ação planejada e intenção empreendedora entre universitários: Analisando preditores e mediadores. Revista Psicologia: Organizações e Trabalho, 16(1), 22-35. doi:10.17652/rpot/2016.1.706

Lopez Jr., G. S., \& Souza, E. C. L. (2008). Atitude empreendedora: Conceitos, modelos e medidas. Anais do Simpósio de Gestão da Inovação Tecnológica, Brasília, DF, Brasil 25.

Lowik, S., Kraaijenbrink, J., \& Groen, A. (2016). The team absorptive capacity triad: A configurational study of individual, enabling, and motivating factors. Journal of Knowledge Management, 10(5), 1083-1103, doi:10.1108/ JKM-11-2015-0433

Martins, F. S., Santos, E. B. A., \& Silveira, A. (2019). Intenção empreendedora: Categorização, classificação de construtos e proposição de modelo. Brazilian Business Review, 16(1), 46-62. doi:10.15728/bbr.2019.16.1.4

Matte, A., Spavenello, R. M., Lago, A., \& Andreatta, T. (2019). Agricultura e pecuária familiar: (Des)continuidade na reprodução social e na gestão dos negócios. Revista Brasileira de Gestão e Desenvolvimento Regional, 15(1), 19-33.

Meirelles, D. S., \& Camargo, A. B. (2014). Capacidades dinâmicas: O que são e como identificá-las? Revista de Administração Contemporânea, 18 (ed. esp.), 41-64. doi:10.1590/1982-7849rac20141289 
Minbaeva, D., Pedersen, T., Björkman, I., \& Fey, C. F. (2014). A retrospective on: MNC knowledge transfer, subsidiary absorptive capacity, and HRM. Journal of International Business Studies, 45(1), 52-62.

Moraes, G. H. S. M., Iizuka, E. S., \& Pedro, M. (2018). Effects of entrepreneurial characteristics and university environment on entrepreneurial intention. Revista de Administração Contemporânea, 22(2), 226-248.

Obschonka, M., Silbereinsen, R. K., \& Schmitt-Rodermund, E. (2010). Entrepreneurial intention as developmental outcome. Journal of Vocational Behavior, 77(1), 63-72.

Oliveira, W. M., \& Vieira Filho, J. E. R. (2018). Sucessão nas fazendas familiares: Problemas e desafios (Texto para discussão). Brasília: Instituto de Pesquisa Econômica Aplicada. Retrieved from http://repositorio.ipea.gov.br/ bitstream/11058/8358/1/td_2385.pdf

Paiva, L. E. B., Lima, T. C. B., Rebouças, S. M. D., Ferreira, E. M. D. M., \& Fontenele, R. E. S. (2018). Influência da sustentabilidade e da inovação na intenção empreendedora de universitários brasileiros e portugueses. Cadernos EBAPE.BR, 16(4), 732-747.

Peterman, N. E., \& Kennedy, J. (2003). Enterprise education: Influencing student's perceptions of entrepreneurship. Entrepreneurship Theory and Practice, 28(2), 129-144.

Riel, A. C. R., Henseler, J. van, Kemény, I., \& Sasovova, Z. (2017). Estimating hierarchical constructs using consistent partial least squares: The case of second-order composites of common factors, Industrial Management $\mathcal{E}$ Data Systems, 117(3), 459-477. doi:10.1108/IMDS-07-2016-0286

Saeed, S., Yousafzai, S. Y., Yani-De-Soriano, M., \& Muffatto, M. (2015). The role of perceived university support in the formation of students' entrepreneurial intention. Journal of Small Business Management, 53(4), 1127-1145. doi:10.1111/jsbm.12090

Sciascia, S., D’Oria, L., Bruni, M., \& Larrañeta, B. (2014). Entrepreneurial orientation in low-and medium-tech industries: The need for absorptive capacity to increase performance. European Management Journal, 32(5), 761-769. doi:10.1016/j.emj.2013.12.007

Shapero, A. (1984). The entrepreneurial event. In C. A. Kent (Ed.). The Environment for Entrepreneurship (pp. 21-40). Lexington: D. C. Heath.

Shapero, A., \& Sokol, L. (1982). The social dimensions of entrepreneurship. In A. K. Calvin, D. L. Sexton, \& K. H. Vesper. Encyclopedia of Entrepreneurship. Englewood Cliffs: Prentice-Hall. 
Shaver, K. G., \& Scott, L.R. (1991). Person, process, choice: The psychology of new venture creation. Entrepreneurship Theory and Practice, 16 (2), 23-45.

Silva, E. R., D’Arrigo, F. P., Furlan, J. Ganzer, P. P., Olea, P. M., Larentis, F., Dorion, E. C. H., Nodari, C. H., Radaelli, A. A. P., \& Prodanov, C. C. (2016). Capacidade absortiva individual: Uma perspectiva com alunos de Administração. Revista Espacios, 37(1), 2-11.

Souitaris, V., Zerbinati, S., \& Al-Laham, A. (2007). Do entrepreneurship programs raise entrepreneurial intention of science and engineering students? The effect of learning, inspiration and resources. Journal of Business Venturing, 22 (4), 566-591.

Souza, R. S., \& Silveira, A. (2016). Intenção empreendedora: Validação do Entrepreneurial Intention Questionnaire (EIQ) em contexto brasileiro. Anais do Encontro Nacional dos Programas de Pós-Graduação em Administração, Brasil, 17.

Sznitowski, A. M., \& Souza, Y. S. (2016). Capacidade de assimilação de conhecimentos e tecnologias no setor primário: Estudo de casos em grandes propriedades rurais produtoras de soja. Organizações Rurais \& Agroindustriais, 18(2), 171-185.

Tian, A. W., \& Soo, C. (2014). Absorptive capacity and creative performance at the individual level. ANZAN Conference, Australian and New Zealand Academy of Management, Sidney, Australia. Retrieved from https://www. anzam.org/wp-content/uploads/pdf-manager/1723_ANZAM-2014379.PDF

Todorova, G., \& Durisin, B. (2007). Absorptive capacity: Valuing a reconceptualization. Academy of Management Review, 32(3), 774-786. doi:10.2307/ 20159334

Van Den Bosch, F., Volberda, H. W., \& Boer, M. de (1999). Coevolution of firm absorptive capacity and knowledge environment: Organizational forms and combinative capabilities. Organization Science, 10, 551-568.

Vega-Jurado, J., Gutiérrez-Gracia, A., \& Fernández-de-Lucio, I. (2008). Analyzing the determinants of firm's absorptive capacity: Beyond R\&D. $R \& D$ Management, 38, 392-405.

Versiani, A. F., Cruz, M. A., Castro, J. M., Ferreira, M. A. T., \& Guimarães, L.O. (2010). Mensuração da capacidade absortiva: até que ponto a literatura avançou? Anais do Encontro Nacional dos Programas de Pós-Graduação em Administração, Brasil, 26. 
Volberda, H. W., Foss, N. J., \& Lyles, M. A. (2010). Absorbing the concept of absorptive capacity: How to realize its potential in the organization field. Organization Science, 21(4), 931-951. doi:10.1287/orsc.1090.0503

Wheisemer, N. (2019). Situação juvenil e projetos profissionais de jovens agricultores familiares no Recôncavo da Bahia. Estudos Sociedade e Agricultura, 27(1), 67-94.

Yildiz, H. E., Murtic, A., Zander, U., \& Richtnér, A. (2019). What fosters individual-level absorptive capacity in MNCs? An extended motivationability-opportunity framework. Management International Review, 59(1), 93-129. doi:10.1007/s11575-018-0367-x

Zahra, S. A., \& George, G. (2002). Absorptive capacity: A review, reconceptualization, and extension. Academy of Management Review, 27(2), 185-203. doi:10.5465/amr.2002.6587995

Zollo, M., \& Winter, S. G. (2002). Deliberate learning and the evolution of dynamic capabilities. Organization Science, 13, 339-351. 


\section{AUTHOR NOTES}

Claudete C. Santos, master from the Postgraduate Program in Administration, University of Vale do Itajaí (Univali); Sayonara F. Teston, doctor from the Postgraduate Program in Administration, University of Vale do Itajaí (Univali); Patrick Zawadzki, master from the Postgraduate Program in Human Movement Sciences, Santa Catarina State University (Unoesc); Suzete A. Lizote, doctor from the Postgraduate Program in Administration and Tourism, University of Vale do Itajaí (Univali); Hilka P. V. Machado, doctor from the Postgraduate Program in Production Engineering, Federal University of Santa Catarina (UFSC).

Claudete C. Santos is now professor at the graduation in Business Administration of Catarinense Federal Institute (IFC); Sayonara F. Teston is now professor at the professional master in Administration of University of Western Santa Catarina (Unoesc); Patrick Zawadzki is now professor at the Graduation in Physical Education of University of Western Santa Catarina (Unoesc); Suzete A. Lizote is now professor at the Postgraduate Program in Administration of University of Vale do Itajaí (Univali); Hilka P. V. Machado is now professor at the master in Professional Administration and doctorate in Academic Administration of University of Western Santa Catarina (Unoesc) and in the University Center of Maringá (Unicesumar).

Correspondence concerning this article should be addressed to Sayonara F. Teston, Avenida Nereu Ramos, 3777-D, Seminário, Chapecó, Santa Catarina, Brazil, CEP 89813-000.

E-mail: sayonara.teston@unoesc.edu.br

\section{EDITORIAL BOARD}

Editor-in-chief

Gilberto Perez

Associated Editor

Glória Charão Ferreira

Technical Support

Vitória Batista Santos Silva

\section{EDITORIAL PRODUCTION}

Publishing Coordination

Jéssica Dametta

Editorial Intern

Paula Di Sessa Vavlis

Language Editor

Daniel de Almeida Leão

\section{Layout Designer \\ Emap}

Graphic Designer

Libro 